\title{
Wound Healing Effects of Edible Bird's Nests Oinment (Aerodramus fuciphagus) in Alloxan-Induced Male Rats
}

\author{
Dita Ayulia Dwi Sandi*, Yaumi Musfirah \\ Sekolah Tinggi Ilmu Kesehatan Borneo Lestari, Banjarbaru
}

\begin{abstract}
Edible bird's nest (Aedrodramus fuchipagus) contains EGF (Epidermal Growth Factor) and sialic acid which is useful in wound healing. The aim of this study was to investigate the effect of edible bird's nest on the injured Alloxan-induced rats to form optimal ointment formulation of edible bird's nest (Aedrodramus fuchipagus) which can heal wounds. The method used in this research is experimental using 25 Sprague Dawley rats divided into 5 groups in which each group consists of 5 rats; Group I was the control group (Vaseline + Betadine ${ }^{\circledR}$ ), Group II, III, and IV were the group of EBN + Betadine ${ }^{\circledR}$ with concentrations of $10 \%, 20 \%$, and $30 \%$; and Group V was of the Sanoskin Meladerm ${ }^{\circledR}(\mathrm{SM})+$ Betadine $₫$ group. The rats were modeled for diabetes by inducing Alloxan (150 mg/kgBW/i.p) and exposed with DM when the blood sugar level was $>200 \mathrm{mg} / \mathrm{dL}$. The back skins were sliced as long as $2 \mathrm{~cm}$ and $2 \mathrm{~mm}$ depth and were given treatment according to the group, $1 \mathrm{x}$ daily for 10 days. Parameters that were noticed were length wound, length of the dry wound, and the number of days of scab formation. The results obtained in the control group were $10 \%, 20 \%$, and $30 \%$ on the EBN group, and the SM group on the 9th day were $1.3 \pm 0.2449,0.34 \pm 0.427$, $0.56 \pm 0.4586,0 \pm 0,0 \pm 0$. The results of the average length of the dry wound in the control group were $10 \%$, $20 \%$, and $30 \%$ on the EBN group, and the SM group were $1 \pm 0.5,2 \pm 1.5,4 \pm 0,8,1 \pm 0.8$, and $2 \pm 0.63$. While the result of the average day of scab formation on the control group was $10 \%, 20 \%$, and $30 \%$ on the EBN groups, SM Groups were $1.3 \pm 0.47,2.2 \pm 1.6,3.8 \pm 0.8,1 \pm 0$, and $2 \pm 0.63$. Based on Kruskal Wallis test, there were significant differences in the wound length among treatment groups (sig 0.013) and significant differences in dry wounds among treatment groups (sig 0.046), but there was no difference in the time of scab formation among treatment groups (sig 0.066). In conclusion, edible bird's nest (Aedrodramus fuchipagus) ointment concentration of $30 \%$ is the most optimal ointment to wound healing in Alloxan-induced male rats when compared to Sanoskin Melladerm.
\end{abstract}

Keywords: Edible Bird's nest, Aerodramus fuciphagus, wound healing, diabetic mellitus rats

\section{INTRODUCTION}

In traditional medicine, herbal-based drugs have been reported to exhibit curative value for various disorder. Indonesia is the world's largest producer of swallow nests (Aerodramus fuchipagus) with a production of 500-600 tons in the period of 2011 (IETO Taiwan, 2011).

Diabetes mellitus is a chronic metabolic disorder caused by the pancreas not producing enough insulin or the body cannot use insulin effectively. In Type 2 Diabetes mellitus, the symptoms that are complained about are generally almost nonexistent. Patients with Type 2 diabetes are generally more susceptible to infection, have difficulty recovering from wound healing, have poorer vision, and generally suffer from hypertension, hyperlipidemia, obesity, and also complications in blood vessels and nerves (Depkes RI, 2005).

Wound healing is a complex and dynamic process to restore cell structure and tissue layers. Wound healing in adult can be divided into 3

\footnotetext{
*Corresponding author : Dita Ayulia Dwi Sandi
} Email : ditaayulia@stikesborneolestari.ac.id phases: the inflammatory phase, the proliferation phase, and the remodeling phase. When a wound occurs, the body will react by constricting blood vessels in the area around the wound, followed by platelet aggregation and the formation of fibrin (thrombus). After that neutrophil infiltration, monocyte infiltration which then differentiates into macrophages, and lymphocyte infiltration. This is called the inflammatory phase. The proliferation phase is characterized by the occurrence of reepithelization, new blood vessel formation (angiogenesis), collagen synthesis and the formation of extra cellular matrix (ECM), namely glycosaminoglycan (GAGs). After that the wound changes are in a constant state called the remodeling phase which can last for years, in this phase, there is remodeling from collagen and the maturation and regression of blood vessels. In the healing phase of the wound, a variety of growth factors are released and have important and varied roles such as modulators, chemotactic and mitogen agents (Mercandetti, 2011).

The evidence of wound healing of edible bird's nest have already been reported in the 
Tabel I. Formulation of Edible Bird's Nest (Aerodramus fuchipagus) Oinment

\begin{tabular}{llll}
\hline Materials & \multicolumn{1}{c}{ Formulation(\%) } \\
\cline { 2 - 4 } & I & II & III \\
\hline Edible Bird's nest & 10 & 20 & 30 \\
Adeps lanae & 3 & 3 & 3 \\
Stearyl alkohol & 3 & 3 & 3 \\
White wax & 8 & 8 & 8 \\
White petrolatum & 75.5 & 65.5 & 55.5 \\
Nipagin & 0.3 & 0.3 & 0.3 \\
Nipasol & 0.2 & 0.2 & 0.2 \\
Total (g) & 25 & 25 & 25 \\
\hline
\end{tabular}

previous study. Moreover, due to the presence of EGF (Epidermal Growth Factor) in the edible bird's nest, it was found to healing effects (Gope 2007; Kong et al., 1987). The wound healing effect of the edible bird's nest (Aerodramus fuchipagus) because of its chemical content, including glycoproteins, carbohydrates, amino acids, and mineral salts. The main carbohydrates found in the edible bird's nest (Aerodramus fuchipagus) are sialic acid consisting of $\mathrm{N}$-acetylneuraminic acid $(10.8 \% \pm 0.76)$, galactosamine $(4.19 \%)$, glucosamine $(5.3 \%)$, galactose $(5,03 \%)$ and fucosa (0.44\%). The edible bird's nest (Aerodramus fuchipagus) from Indonesia contain greater Glucosamine and N-acetylneuraminic acid (components of sialic acid) than edible bird's nest (Aerodramus fuchipagus) from Thailand and Vietnam (Tung, et al., 2008). Glucosamine is a glycosaminoglycan precursor. Glycosaminoglycan, which is similar to the Extracellular matrix, is considered to play an important role in wound safety which can be attributed to the growth of factors and cytokines and change cell relationships (Nakagawa, et al., 2007; Rolfe \& Grobbelaar, 2012).

With regards to above-mentioned facts, the present study was, therefore, undertaken to evaluate the wound healing property in alloxaninduced diabetic rats by topical administration of Swallows nest ointment.

\section{METHODOLOGY \\ Materials}

The edible bird's nest (Aerodramus fuchipagus), Alcohol $70 \%$ (Brataco), Vaseline alba (Brataco), Sanoskin Meladerm ${ }^{\circledR}$ (Interbet), Betadine ${ }^{\circledR}$ (PT. Mahakam Beta Farma). Sparague Dawley Rats (150-250 g, $\pm 2,5-3$ month)

\section{Ointment Preparation}

Absorption basic ointment and The edible bird's nest was prepared by standard method. Detail of ingredients for the formulation of ointment from Edible Bird's nest is presented in the (Table I) (Sandi \& Musfirah, 2018).

\section{Evaluation of Wound Healing}

Male SD rats weighing between 150-250 g were used. The rats were collected from Indonesian Islamic University. They were housed in cages in groups of three rats per cage and were kept in room light-dark cycle and were allowed to acclimatize for two weeks before the experiments. Detail of groups for the animal groups is presented in the (Table II).

After two weeks, blood glucose level was measured by glucometer (normal blood glucose level) and then, the animal groups were injected by intraperitoneal route with Alloxan monohydrate $(150 \mathrm{mg} / \mathrm{Kgbw})$ in normal saline. After 2 days, the blood glucose level was measured by glucometer to confirm the diabetic status of the animals. The animals showing diabetic if the blood glucose level was $>200 \mathrm{mg} / \mathrm{dL}$ (Tuhin et al., 2017). The limit of normal blood sugar levels of mice is $60-150 \mathrm{mg} / \mathrm{dl}$ (Butler, 1995).

After the rats were confirmed diabetes mellitus, then a wound was made on the skin of the rat's back. First, the hair around the skin of the rat's back was shaved $3 \mathrm{~cm}$ in diameter. This treatment was carried out the same for all test animals. The wound was performed by making a $2 \mathrm{~cm}$ long incision with a depth of $2 \mathrm{~mm}$ using the number 11 sterile scalpel. Then, the length of the initial wound was measured before being treated. Mice that have been injured are then treated according to (Table II).

The treatment was given 2 times a day after making the wound (day 0) until the 10th day. The treatment was given $200 \mathrm{mg}$ by applying it on the wound. Observations were made on day 1 (24 hours after making the wound) until the 10th day after treatment (according to the proliferation phase during wound healing) including the length of the wound dry, when the scab formed and the diameter of the wound. 
Table II. Animal groups

\begin{tabular}{ll}
\hline Kelompok + Betadine $®$ & Konsentrasi (\%) \\
\hline Control & - \\
& 10 \\
EBN & 20 \\
& 30 \\
Sanoskin Melladerm Plus & 20 \\
\hline
\end{tabular}

* Control : Vaselin

\section{Data Analysis}

The values are represented as mean \pm SE and statistical significance between treated and control groups were analyzed using one-way analysis of variance (ANOVA).

\section{RESULTS AND DISCUSSION}

Alloxan was chosen as an inducer of diabetes mellitus because of its ability to form chelat with $\mathrm{Zn}$ in pancreatic Langerhans cells which inhibits insulin production (Sunaryo et al., 2012). Observations were made for 10 days because according to research conducted by Fitriani (2016) on day 3-10 will occur granulation formation, namely the formation of fibroblasts and inflammatory cells. The results of the observation of average of wound length for 10 days (Table III and Figure 1).

On day 5 (Table III), EBN Groups with concentration 10\%, 20\%, and 30\% had significantly different values ( $\mathrm{P}$ 0.056; $\mathrm{P}$ 0.071) with the negative control group. EBN Groups with concentration 30\% had significant differences with EBN Groups with concentration 10\% (P 0.017) and $20 \%$ (0.015), but EBN Groups with concentration $30 \%$ did not have a significant difference with the SM group (P 0.700).

On day 9, observation for EBN Groups with concentration $20 \%$ with the control group did not differ significantly to the reduction wound length, while EBN Groups with concentration 10\% and $30 \%$ had a significant difference to the reduction wound length ( $P$ 0.005; 0.005) compared to negative controls. Reduction in wound length of EBN Groups with concentration $10 \%$ and $30 \%$ was more than the negative control.

According to research by (Tung et al., 2007), reduction wound length of edible bird's nest occurs because Edible Bird's Nest (Aerodramus fuchipagus) contains sialic acid. Sialic acid components in Edible Bird's Nest consist of $\mathrm{N}$ acetylneuraminate, galactosamine, galactose, and fucose acids (Tung et al., 2007). Sialic acid can accelerate wound healing which has a role in cell division or the formation of new cells (Irma, 2014). Inside edible bird's nest (Aerodramus fuchipagus), there is also a growth factor. According to Gope (2007), EGF (Epidermal Growth Factor) plays an important role in wound healing that is in the process of re-revitalization. Re-revitalization is also called epithelial regeneration wherein the cells in the basal layer migrate towards the surface to supply cells in the more superficial layer, and this movement is accelerated by the presence of injury (Kalangi, 2013). Sanoskin Melladerm $\AA$ contains eco honey, glycerin, propylene glycol, PEG 4000 which has the ability to stimulate the wound healing process so that the healing becomes faster.

In the observation of length of dry wound (Table IV), there was no significant difference between the negative control group with EBN Groups with concentration 10\% (P 0.054), EBN Groups with concentration 30\% (P 0.817) and SM Group and there were significant differences between EBN Groups with concentration 20\% (P 0.007). The length of dry wound affected by the environment, the moist wound environment is the most optimal environment to heal wounds. Diabetes mellitus causes blood sugar levels to increase and lead to stiffness in blood vessels, so that blood cannot reach the wound and consequently the wound becomes long to dry and the recovery time is also long. The data indicate that the EBN Groups has a concentration of $10 \%$, $30 \%$, and the SM group has the average length of a the dry wound on day 1-2.

Based on Table $\mathrm{V}$, the results of the analysis showed that there was no significant differences day of scab formation between the five groups. Based on research from (Aponno et al., 2014) that the speed of scab formation shows the speed of wound healing. Scab formation of EBN Groups with concentration $30 \%$ occurs on day $1 \pm 0$, because environmental conditions of the wound become dry so scab formation quickly, this is because EBN can absorb the humid environment and because of the EGF in the EBN (Aedrodramus fuchipagus) has an important role in wound healing so that wound healing becomes more rapidly formed scab. Process of forming a scab shows the process of wound healing that enters early stage proliferation (Fitriyani, 2016). Scab formed wounds can form 


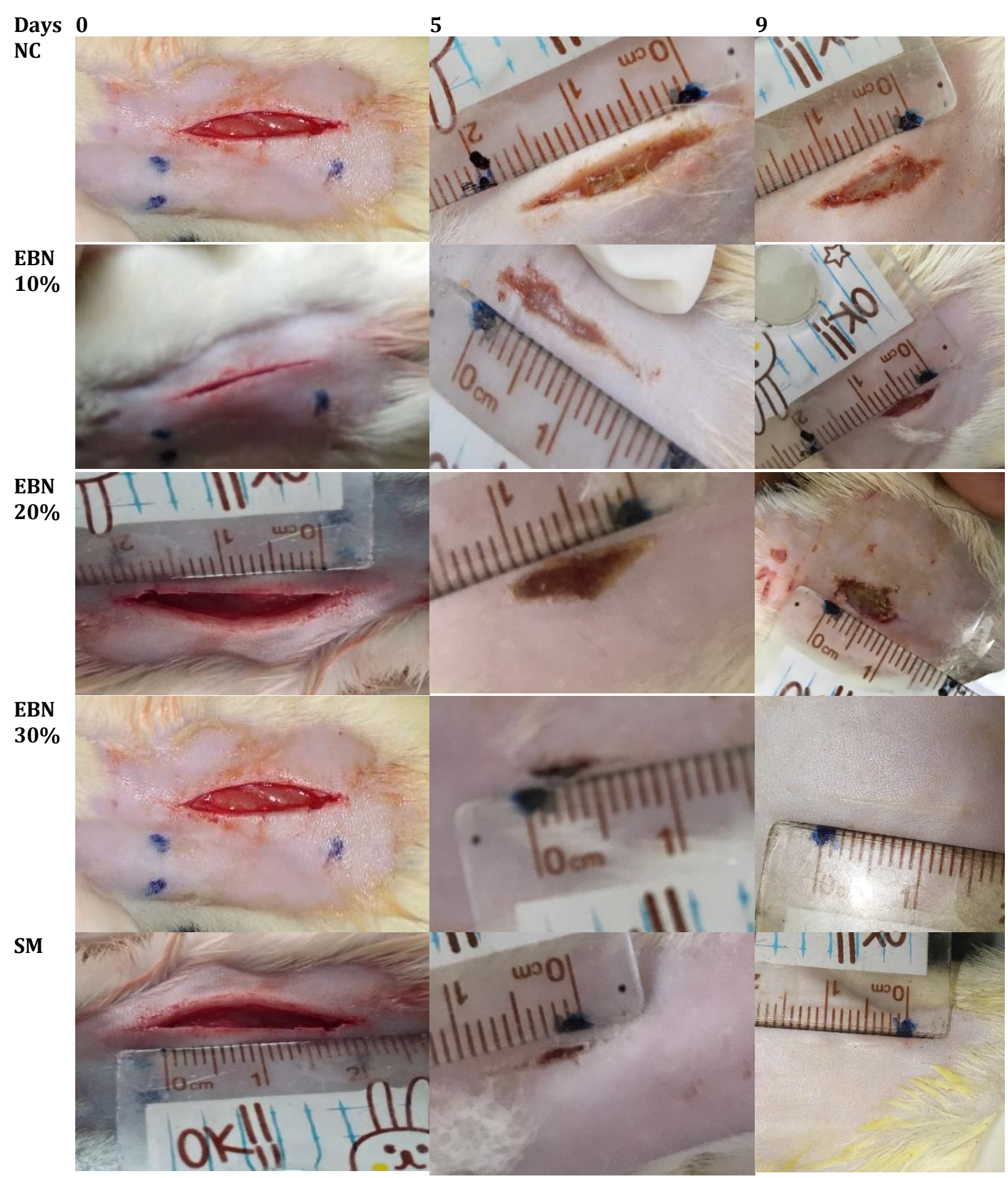

Figure 1. Wound Length Day 0-9

hemoestatis and prevent contamination of wounds by microorganisms. This phase is characterized by the formation of granulation tissue in the skin (fibroblasts and inflammatory cells).

Based on data average of wound length, the average length of dry wound and an average day of scab formation. Edible Bird's Nest (Aedrodramus fuchipagus) with concentration $30 \%$ took 9 days to reduce the wound length until $0 \mathrm{~cm}$. It showed EBN Groups with concentration $30 \%$ had a significant difference to the reduction wound length (P 0.005) compared to negative controls and had a no significant difference ( $P$ 0.700) to the reduction wound length compared to SM Groups. Reduction in wound length of EBN Groups with concentration $30 \%$ was better than the negative control. 


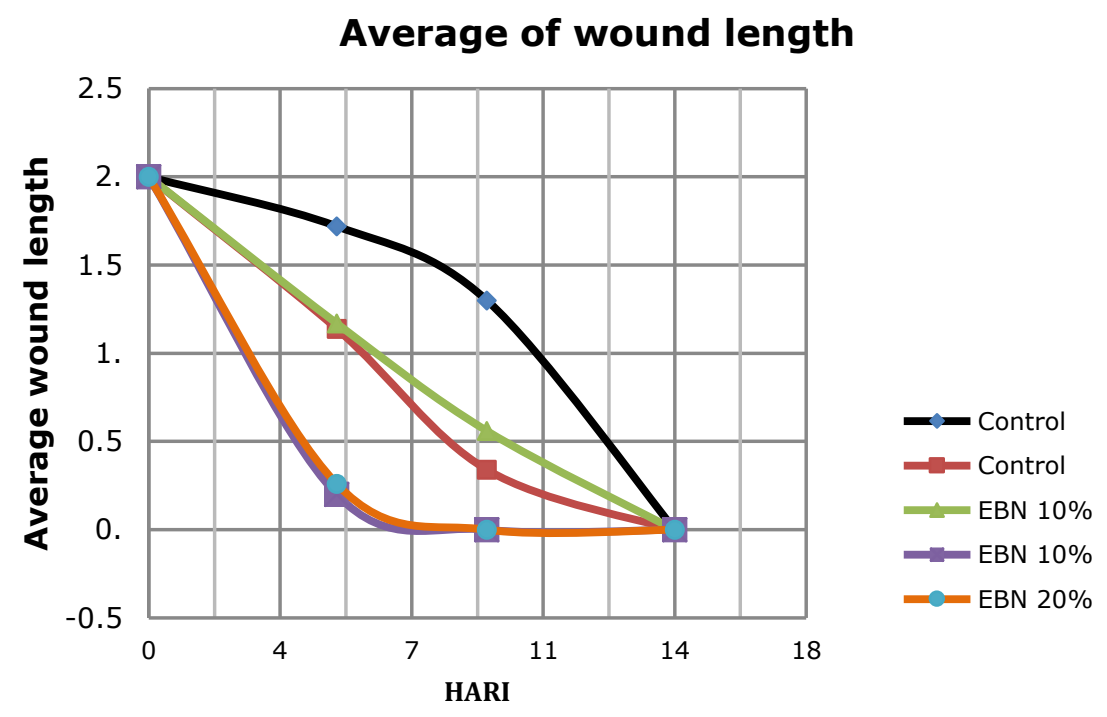

Figure 2. Average of wound length

Table III. Average of Wound Length

\begin{tabular}{lcccc}
\hline \multirow{2}{*}{ Group + Betadine ${ }^{*}$} & \multirow{2}{*}{ Concentration (\%) } & \multicolumn{3}{c}{ Day of Average of wound length (cm) \pm SD } \\
\cline { 3 - 5 } & & $\mathbf{0}$ & $\mathbf{5}$ & $\mathbf{9}$ \\
\hline Control & - & $2 \pm 0$ & $1.72 \pm 0.40$ & $1.3 \pm 0.25$ \\
& 10 & $2 \pm 0$ & $1.14 \pm 0.29$ & $0.34 \pm 0.43^{*}$ \\
EBN & 20 & $2 \pm 0$ & $1.17 \pm 0.24$ & $0.56 \pm 0.46$ \\
& 30 & $2 \pm 0$ & $0.2 \pm 0.4^{*}$ & $0 \pm 0^{*}$ \\
Sanoskin Melladerm $\AA$ & 20 & $2 \pm 0$ & $0.26 \pm 0.33^{*}$ & $0 \pm 0^{*}$ \\
\hline
\end{tabular}

Source: Original data processed; ${ }^{*} \mathrm{EBN}=$ Edible Bird's Nest; ${ }^{*} \mathrm{P}<0.05$ : Significantly different from negative controls

Table IV. Average Length of Dry Wound

\begin{tabular}{lll}
\hline Groups +Betadine ${ }^{\circledR}$ & Concentration & Average length of dry wound (day) \pm SD \\
\hline Control & - & $1 \pm 0.4898$ \\
& $10 \%$ & $2 \pm 1.4966$ \\
EBN & $20 \%$ & $4 \pm 0.8^{*}$ \\
& $30 \%$ & $1 \pm 0.8$ \\
\hline
\end{tabular}

Source: Original data processed; * EBN = Edible Bird's Nest; ${ }^{*} \mathrm{P}<0.05$ : Significantly different from controls

Data of average length of dry wound and the average day of scab formation, Edible Bird's Nest (Aedrodramus fuchipagus) with concentration 30\% had a no significant difference to the compared to negative controls and SM Groups. The average length of dry wound of EBN 30\% showed the same with the control negative was on day 1 , and it was better than Average length of the dry wound of SM Groups. Thus, Average day of scab formation, Edible Bird's Nest (Aedrodramus fuchipagus) with concentration $30 \%$ had a no significant difference to the compared to negative controls and SM Groups. The average day of scab formation of EBN $30 \%$ showed on day 1 , and it was better than the average length of the dry wound of the negative control (on day 1.3) and SM Groups (on day 2).

\section{CONCLUSION}

The wound healing effect in Alloxaninduced male rats was seen based on the results of the Kruskal Wallis test. There were significant differences in the wound length among treatment groups (sig 0.013). There were also significant differences in dry wounds among treatment groups (sig 0.046). Meanwhile, there was no difference in the time of scab formation between among groups (sig 0.066). Edible bird's nest (Aedrodramus fuchipagus) ointment 


\section{Average Length of Dry Wound}

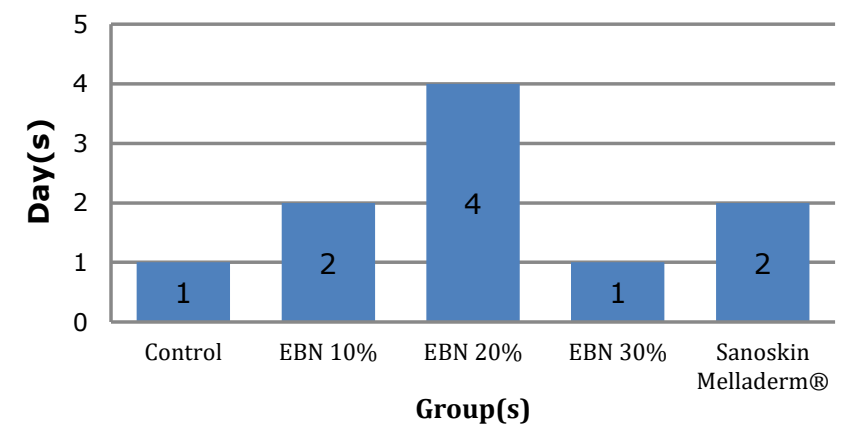

Figure 3. Average Length of Dry Wound

\section{Average Day of Scab Formation}

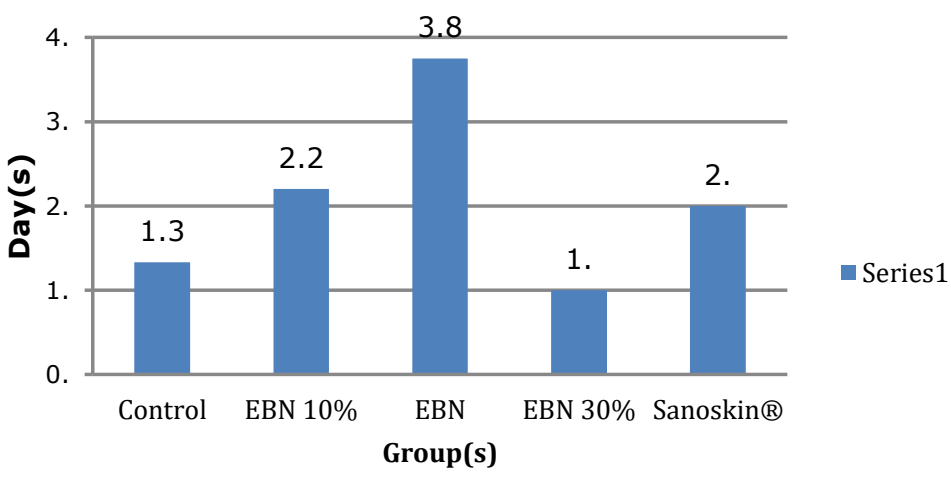

Figure 4. Average Day of Scab Formation

Table V. Average Day of Scab Formation

\begin{tabular}{lcc}
\hline Groups +Betadine ${ }^{\circledR}$ & Concentration & Average length of dry wound (day) \pm SD \\
\hline Control & - & $1.3 \pm 0.4714$ \\
& $10 \%$ & $2.2 \pm 1.6$ \\
EBN & $20 \%$ & $3.8 \pm 0.8$ \\
& $30 \%$ & $1 \pm 0$ \\
Sanoskin Melladerm $\AA$ & $20 \%$ & $2 \pm 0.6324$ \\
\hline
\end{tabular}

Source: Original data processed; * EBN = Edible Bird's Nest; * P <0.05: Significantly different from controls

concentration $30 \%$ is the most optimal ointment to wound healing in male rats that are induced by Alloxan when compared to Sanoskin Melladerm.

\section{ACKNOWLEDGMENT}

This research was funded by research grants from the Ministry of Research and Technology and Higher Education Republic of Indonesia (2018).

\section{REFERENCES}

American Diabetes Association. 2003. Peripheral arterial diseasein people with diabetes. Diabetes care. 26 (12) : 3333-3341.

American Diabetes Association. 2017. Standars of medical care in diabetic - 2017. The journal of clinical and applied research and education. 40 (1).

Butler, L.K. 1995. Regulation of Blood Glucose 
Levels in Normal and Diabetic Rats. Texas: Divisiun of Biological Sciences. 181-202.

Colombo JP, Garcia-Rodenas C, Guesry PR \& Rey J. 2003. Potential effects of supplementation with amino acids, choline or sialic acid on cognitive development in young infants. Acta Paediatr Suppl. 92: 42-46.

Depkes RI. 2005. Pharmaceutical Care untuk penyakit Diabetes Mellitus. Departemen Kesehatan Republik Indonesia. Jakarta.

Dinar, D.D., Nashrullah \& Prasetyo, T.A. 2005. Prototipe Alat pengering (Non Vacum) pada Industri pencucian Sarang Walet. Jurnal Teknik Mesin (ISSN 1829-8958). Vol. 2 No. 2.

Fitriani, N. 2016. Uji Aktivitas Gel Etil PMetoksinamat terhadap Penyembuhan Luka Terbuka pada Tikus Putih (Rattus novegicus) Jantan. Skripsi. UIN Syarif Hidayatullah, Jakarta.

Hamzah, Z., Ibrahim, N.H., Sarijini, Hussin, K., Hashim, O. \& Lee, B.B. 2013. Nutritional Properties of Edible Bird Nest. Journal of Asian Scientific Research. 3(6): 600-607.

Hussain, H.E.M. 2002. Reverse of Diabetic Retinopathy in Streptozotocin Induced Diabetic Rats Using Traditional Indian Anti Diabetic Plan Azadirachta indika (L). Indian J. Clin. Biochem. 17:115-1.

Irma. 2014. Pemberian krim ekstrak sarang burung walet $10 \%$ meningkatkan epitelisasi pada penyembuhan luka kulit mencit (Mus musculus). Tesis. Universitas Udayana Denpasar.

Kantor Dagang dan Ekonomi Indonesia di Taiwan. 2012. Market brief Peluang ekspor sarang burung walet di pasar Taiwan. KDEI di Taiwan. Taiwan.

Keputusan Kepala Badan Karantina Pertanian. 2010. Keputusan Kepala Badan karantina Pertanian Nomor: 374/Kpts/KH.210/L/5/ 2010 tentang Petunjuk Teknis Penanganan dan Pemeriksaan Sarang
Burung Walet dan Sriti, Badang Karantina Pertanian. Jakarta.

Konsul Perdangan. 2016. Laporan Market Brief : edisi Januari 2016 Sarang Burung Walet di Pasar Hongkong. Konsulat Jenderan Republik Indonesia Hongkong SAR. Republik Rakyat Tiongkok.

Nakagawa, H., Hama, Y., Sumi, T., Li, S., Maskos, K., Kalayanamitra, K., Mizumoto, S., Sugahara, K. \& Teh, L. 2007. Occurrence of a nonsulfated chondroitin proteoglycan in the dried saliva of Collocalia swiftlets (edible bird's-nest). Glycobiology. 17 (2) : 157-164.

Norhayati, M.K., Azman \& Nazaimoon, W. 2010. Preliminary Study of the Nutritional Content of Malaysian Edible Bird's Nest. Mal J Nutr. 16 (3) : 389-396.

Padmadisastra, Y., Syaugi, A., \& Anggia, S. 2007. Formulasi Sediaan Salep Antikeloidal yang Mengandung Ekstrak Terfasilitasi Panas Microwave dari Herba Pegagan (Centella Asiatica (L.) Urban. Seminar Kebudayaan Indonesia Malaysia Kualalumpur. 28-31 Mei 2007.

Peter, C.Y.G. 2014. Authentication of Edible Bird's Nest using advanced Analytical Techniques and Multivariated Data Analysis. Thesis. National University of Singapore.

Rolf, K.J. \& Grobbelaar, A.O. 2012. A Review of fetal scarless healing. ISRN Dermatology. 2012 : 1-9.

Sandi, D.A.D. \& Musfirah, Y. 2018. Pengaruh Basis Salep Hidrokarbon dan Basis Salep Serap terhadap Formulasi Salep Sarang Burung Walet Putih (Aerodramus fuciphagus). Jurnal Ilmiah Manuntung 4 (2) : 149-155.

Tim Penulis PS. 2009. Panduan Lengkap Walet. Penebar Swadaya. Jakarta.

Tung, C.H., Pan, J.Q., Chang, H.M. \& Chou, S.H. 2008. Authentic determintion of Bird's nests by saccharides profile. Journal of Food and Drug Analysis. 16 (4) : 86-91. 